\title{
Pertanggungjawaban Pidana Bagi Pelaku Pembunuhan yang Mengalami Gangguan Jiwa Perspektif Hukum Pidana dan Islam
}

\author{
Ruslan Abdul Gani \\ Fakultas Syariah Universitas Islam Negeri Sultah Thaha Saifudin Jambi \\ Correspondence email: ruslanabdulgani616@gmail.com
}

\begin{abstract}
Abstrak. Pembunuhan yang dilakukan oleh yang berstatus sebai orang gila merupakan permasalahan yang lumrah terjadi di masyarakat dengan bermacam kasus dan karateristik. Pemberitaan tentang hal tersebut kemungkinan membangkitkan emosi yang kuat dan menimbulkan pertanyaan apakah disanksi ataukah tidak. Berkaitan dengan kejahatan itu sendiri, pandangan dari hukum Islam mengartikan sebuah tindakan kejahatan merupakan sebagai perbuatan yang dilarang oleh hukum yang berasal dari Allah, terhadap pelanggaran tersebut sudah ada ketentuan hukuman yang berasal dari-Nya. Larangan hukum dimaksud disini adalah mengerjakan suatu hal perbuatan-perbuatan yang telah dilarang atau dengan tidak mengerjakan pekerjaan yang tidak dibenarkan.Hal yang dapat digolongkan yang merupakan bagian dari tindakan kejahatan dalam Islam adalah apabila perbuatan itu hanya dilarang atas dasar syariat. Hal ini harus dapat dikatakan, dengan dilakukan atau tidak dilakukannya suatu perbuatan yang akan mengakibatkan kepada suatu hukuman yang harus didasarkan pada syari'at yang merupakan sebuah kejahatan. Perspektif hukum Islam dan dalam ketentuan hukum kepidanaan terhadap perbuatan dalam kategori tindakan kriminal, seperti tindakan dalam kategori pembunuhan, yang diperbuat oleh orang gila atau orang yang sedang mengalami gangguan kejiwaan. Disini akan terlihat apakah ketentuan hukum Islam dan ketentuan hukum kepidanaan juga akan diberlakukan pada orang gila yang telah terbukti dalam hal melakukan tindakan criminal tersebut.
\end{abstract}

Kata Kunci: Pertanggungjawaban Pidana; Gangguan Kejiwaan

Abstract. Murder which is committed by the status of a madman is a common problem in society with various cases and characteristics. Publicity about this is likely to arouse strong emotions and raise the question of whether or not it is sanctioned. In connection with the crime itself, the view from Islamic law defines a crime as an act that is prohibited by law that comes from Allah, for this violation there are provisions of punishment that come from Him. The legal prohibition referred to here is to do an act that has been prohibited or by not doing work that is not justified. What can be classified as part of a crime in Islam is if the act is only prohibited on the basis of the Sharia. It must be said, by doing or not doing an act which will result in a punishment which must be based on the Shari'ah which is a crime. The perspective of Islamic law and in the provisions of criminal law on actions in the category of criminal acts, such as actions in the category of murder, are committed by crazy people or people who are experiencing mental disorders. Here it will be seen whether the provisions of Islamic law and the provisions of criminal law will also apply to a madman who has been proven to have committed these crimes.

\section{Keywords: Criminal Liability Psychiatric Disorders}

\section{PENDAHULUAN}

Pembunuhan yang dilakukan oleh yang berstatus sebai orang gila merupakan permasalahan yang lumrah terjadi di masyarakat dengan bermacam kasus dan karateristik. Pemberitaan tentang hal tersebut kemungkinan membangkitkan emosi yang kuat dan menimbulkan pertanyaan apakah disanksi ataukah tidak.

Seiring dengan perkembangan zaman, ditambah dengan semangkin meningkatnya kejahatan, yang terjadi dalam kehidupan masyarakat tentu hal ini persoalan, peran negara sebagai pelindung atas keamanan dan ketenraman masyarakat serta pelayan terhadap masyarakat diharapkan dapat mengatasinya. Dalam Islam ada dikenal istilah Syari'at(aturan Allah) yaitu hukumyang abadi dan berlaku sepanjang masa.Dalam kurun waktu yang panjang, sejak dimulai diturunkannya agama Islam sampai akhir masa pemerintahan Turki Usmani, syari'at Islam bagaikan cahaya yang menyinari dan menerangi jalannya kaum muslimin, dan menunjukkan kepada mereka jalan kebenaran dan keadilan.Pada saat itu syari'at Islam dipelajari dengan antusias, dan ditetapkan olehpemerintah, sehingga tidak ada satu pun perundang-undangan didunia ini yang $\backslash$ mengunggulinya. ${ }^{1}$

Berkaitan dengan kejahatan itu sendiri, pandangan dari hukum Islam mengartikan sebuah tindakan kejahatan merupakan sebagai perbuatan yang dilarang oleh hukum yang berasal dari Allah, terhadap pelanggaran tersebut sudah ada ketentuan hukuman yang berasal dari-Nya. Larangan hukum dimaksud disini adalah mengerjakan suatu hal perbuatan-perbuatan yang telah dilarang atau dengan tidak mengerjakan pekerjaan yang tidak dibenarkan.

Hal yang dapat digolongkan yang merupakan bagian dari tindakan kejahatan dalam Islam adalah apabila perbuatan itu hanya dilarang atas dasar syariat. Hal ini harus dapat dikatakan, dengan dilakukan atau tidak dilakukannya suatu perbuatan yang akan mengakibatkan kepada suatu hukuman yang harus didasarkan pada syari'at

${ }^{1}$ Ahmad Wardi Muslich, Hukum Kepidanaan Berdasarkan Al-Qur'an, Diadit Media, Jakarta, 2007, hal. 1. 
yang merupakan sebuah kejahatan. ${ }^{2}$ Jadi kejahatan ataupun tindakan kriminal sama sekali tidak dibenarkan dalam Islam maupun hukum pidana, seperti pencurian, perampokan, perkosaan, penipuan, pemalsuan, pembunuhan dan lain sebagainya karena akibat dari perbuatan tersebut dapat merugikan orang lain.

Selanjutnya dilihat dari hukum pidana, dimana hukum pidana itu sendiri adalah tata cara dan alat yang dapat digunakan untuk tindakan dalam rangka penanggulangan sebuah kejahatan, baik kejahatan yang secara umum, maupun perbuatan yang dalam kategori secara khusus. Penanggulangan itu sendiri adalah segala perbuatan kriminal yang harus ditindak tegas dengan cara sebuah tindakan pencegahan dalam hal ini merupakan kebijakan secara (preventif) maupu sebuah perbuatan penindakan dalam hal ini disebut dengan (represif). Atau dengan cara tindakan pencegahan preventif yang merupakan sebuah cara penanggulangan dengan cara membuat pola untuk melakukan perbuatan untuk tindakan pencegahan, seperti perbuatan dengan cara melakukan menghimbau atau dengan cara tindakan penyuluhan. Cara represif disini merupakan cara untuk melakukan tindakan penaggulangan dengan cara penerapan sebuah pola keras, seperti dengan cara tindakan penangkapan maupun pemenjaraan bahkan hingga dengan sebuah cara penembakan maupun sampai pada tindakan akhir yaitu dengan cara pembunuhan. ${ }^{3}$

Jenis-jenis yang merupakan bagian yang termasuk kedalam sanksi pidana yang dapat diancamkan kepada pelaku merupakan tindak pidana dapat dilihat dalam ketentuan yang merupakan bagian dari hukum pidana positif, dalam hal ini merupakan bagian dari ketentuan Kitab Perundangan Hukum bagian Kepidanaan diatur Pasal nomor 10 KUHP terdiri dari:

1. Ketentuan Pidana pokok, yang termasuk dalam ini adalah:
a. Ketentuan Hukuman Pidana Mati
b. Ketentuan Hukuman Pidana Kurungan
c. Ketentuan Pidana Penjara
d. Ketentuan Pidana Dendadan
e. Ketentuan Pidana tutupan.

2. Ketentuan Kepidanaan tambahan, yang termasuk dalam hal ini adalah :

a. Tindakan terhadap pencabutan atas beberapa hak tertentu

b. Tindakan terhadap perampasan barang yang tertentu, dan

c. Tindakan pengumuman keputusan hakim. ${ }^{4}$

Mengenai perbuatan pidana dalam hal pembunuhan, yang sebagaimana termuat pada ketentuan Hukum Kepidanaan Indonesia mengenai pembunuhan itu telah diatur sebagaimana yang termuat dalam KUHP Pasal nomor Pasal ke 338 hingga pada sampai Pasal ke 350. Pada ketentuan Pasal ke 338 KUHP menyebutkan terhadap: Barangsiapa yang dengan sengaja melakukan perbuatan dengan cara merampas terhadap nyawa atas orang lain, akan dikenakan dengan diancam atas perbuatannya sebagaimana tersebut perbuatan itu meruakan perbuatan yang tergolong pada tindakan pembunuhan, Hal ini akaan di ancam dan akan dihukum dengan ketentuan pidana penjara paling lama lima belas tahun. ${ }^{5}$

Berkaitan terhadap dengan ketentuan hukum kepidanaan, dalam bagian ketentuan hukum pidana yang berasaskan pada hukum yang berasaskan Islam yang dikenal dengan sebutan jarimah. Jarimah (tindak pidana) dalam Islam diartikan mengenai larangan akan syara yang akan diancam pada ketentuan Allah dengan ketentuan hukum hadd atau ta 'zir. Dengan demikian kata jarimah dapat digolongkan menjadi dua macam yaitu hukum had, dan hukum ta 'zir. Sebagai suatu dasar hukum, didalam ketentuan mengenai hukum kepidanaan dalam Islam mengenai perbuatan pembunuhan yang diatur dalam kitab Al- Qur'an ditegaskan yang menyatakan:

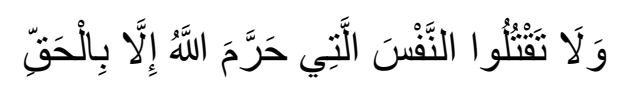

Artinya:"Dan janganlah kamu melakukan sebuah perbuatan yang terhadap tindakan berupa melakukan pembunuhan terhadap jiwa yang dalam hal ini diharamkan oleh Allah (pembunuhan) nya, melainkan tanpa ada suatu alasan yang dalam haq". ${ }^{6}$

Bila diperhatikan lebih jauh lagi yang alam kategori sebagai perbuatan seseorang terhadap tindakannya kedalam perbuatan pembunuhan, perbuatan pidana dalam syari'at Islam dapat di golongkan atau yang dalam hal ini digabungkan berbentuk :Amd (perbuatan secara sengaja) khata'(pebuatan yang dilakukan secara tidak di sengaja), dan

\footnotetext{
${ }^{2}$ Topo Santoso, Membumikan Bagian Ketentuan Hukum Kepidanaan Islam, Gema Insani Press, Jakarta, 2003, hal. 20.

${ }^{3}$ Kun Maryati, Jujun Suryawati, Sosiologi Jilid3, ESIS, 2001, hal. 22

${ }^{4}$ Andi Hamzah, KUHAP Dan KUHP, Cet. Ke- 19, Jakarta: Rineka Cipta, 2015, hal. 5

${ }^{5}$ Ibid, hal. 6

${ }^{6}$ Zainuddin Ali, Pengantar Ilmu Hukum Kepidanaan Islam Di Indonesia, Sinar Grafika, Jakarta, 2006, hal. 125
} 
syibhu amd (perbuatan yang dilakukan dengan semi sengaja). ${ }^{7}$ Pembunuhan yang dilakukan secara sengaja, yaitu pada perbuatan yang dapat dilakukan oleh seseorang dengan cara tujuan untuk melakukan perbuatan pembunuhan terhadap seseorang dengan cara penggunaan alat, yaitu baik dalam hal berupa benda atau sebuah situasi, yang dapat dipandang dalam kategori kelayakan untuk melakukan perbuatan pembunuhan. Perbuatan yang dilakukan oleh seseorang dengan cara tujuan melakukan tindakan dengan tujuan mendidik contohnya pada seorang guru dengan cara melakukan perbuatan pemukulan dengan cara penggaris yang di pukul ke kaki seorang muridnya, dan saat itu muridnya yang dilakukan secara dipukul itu dan mengakibatkan muridnya meninggal dunia, perbuatan itu oleh guru tersebut digolongkan kepada tindakan pembunuhan sybhu amdi (yang dilakukan dengan cara semi disengaja). Dan contohnya terhadap seseorang menebang sebuah pohon tiba-tiba pohon yang ditebangnya tersebut ternyata setelah tumbang menjatuhi orang yang lewat secara tidak disengaja kemudian tiba-tiba lalu meninggal dunia akibat perbuatan orang tersebut, dapat dikatakan sebagai perbuatan dari tindakan dalam kategori pembunuhan yang dilakukan dengan tidak disengaja. $^{8}$

Dengan demikian tentang jarimahini, ada suatu fenomena yang menarik untuk dipelajari yaitu tindak pidana pembunuhan dalam keadaan gangguan jiwa (gila). Sebenarnya bagaimana perspektif hukum Islam dan dalam ketentuan hukum kepidanaan terhadap perbuatan dalam kategori tindakan kriminal, seperti tindakan dalam kategori pembunuhan, yang diperbuat oleh orang gila atau orang yang sedang mengalami gangguan kejiwaan. Disini akan terlihat apakah ketentuan hukum Islam dan ketentuan hukum kepidanaan juga akan diberlakukan pada orang gila yang telah terbukti dalam hal melakukan tindakan criminal tersebut.

\section{METODE}

Atas penelitian oleh penulis ini maka penulis memakai dengan menggunakan jenis penelitian dengan sifat yuridis normatif maka terhadap penelitian ini yang diposisikan kepada aturan baik terhadap norma yang berkaitan dengan perundangan, sedangkan pada konsep pendekatan yang dipakai pada pendekatan dari perundangan serta pendekatan konsep melalui penggunaan beberapa asas-asas hukum yang bersinggungan terkait pada Pertanggungjawaban pidana bagi pelaku pembunuhan yang mengalami gangguan jiwa perspektif hukum pidana dan islam, sedangkan terhadap pembahasan yang dilakukan dengan penggunan yang deduktif untuk memperoleh kesimpulan secara kualitatif.

\section{HASIL DAN PEMBAHASAN}

\section{Pertanggungjawaban Pidana Pada Tindakan Pembunuhan Bagi Pelaku Yang Menderita Gangguan Jiwa Berdasarkan Hukum Pidana Indonesia}

Mengenai sanksi pidana terhadap pelaku yang melakukan perbuatan pembunuhan sebagaimana telah diatur pada Pasal ke 338 sampai pada Pasal ke 350 KUHP, dimana hukuman terberatnya teridiri dari berapa jenis hukuman diantaranya adalah merupakan hukuman pidana mati ataupun pidana penjara dengan seumur hidup ataupun juga dengan selama waktu yang telah ditentukan tertentu, terhadap hukuman ini akan termuat dengan ketentuan paling lama sampai pada hukuman dua puluh tahun sebagaimana termuat pada pasal ke 340, sedangkan, terhadap dengan hukuman yang paling ringan dapat dikenakan kepada tersangkanya atas hak sebagaimana termuat pada ketentuan Pasal ke 35 dengan Nomor 1 samapai dengan Nomor 5 pada pasal ke 350. Namun semua sanksi pidana tersebut tidak berlaku untuk orang gila atau tidak berakal sebagaimana yang dijelaskan berikut ini.

Sebagimana yang telah diatur pada ketentuan Kitab Undang-Undang Hukum Kepidanaan, dimana disebutkan bahwa ketidak mampuan seseorang untuk melakukan sikap bertanggungjawab sebagaiamana telah termuat pada ketentuan Pasal ke 44 dengan ditandai dari salah satu bahkan terhadap dua hal, yaitu: yang berhubungan atau berkaitan dengan sifat seseorang erat kaitannya dengan sifat gangguan pada kejiwaannya yang telah mengalami kecacatan tau mengalami gangguan ataupun ysng secara langsung kejiwaannya telah terganggu diakibatkan oleh penyakit. Ketidak mampu dari sikap bertanggungjawabnya ini merupakan adalah tidak lain yang merupakan sikap atas ketidak normalan dalam hal ini pada "kondisi" dimana batin pembuat tersebut, telah mengalai atau telah mengidap gangguan kejiwaaan atau telah ada penyakit kejiwaan sebelumnya, sehingga apa yang telah dilakukan bahkan telah dituduhkan padanya tidak akan mampu memenuhi persyaratan dalam kondisi dimana apakah akan dapat patut dicela ataupun tidak atas perbuatan yang telah dilakukan sebelumnya. Hal ini akan menjadikan, dengan kata lain bahwa seseorang tersebut akan dipandang mampu bertanggungjawab jika tidak ditemukan kondisi-kondisi yang telah ditentukan tersebut. ${ }^{9}$

${ }^{9}$ Choirul Huda, Berawal Pada Konsep Tiada Kepidanaan Tanpa Sebuah Kesalahan Menuju Tidak Adanya Pertanggungjawaban Kepidanaan tanpa sebuah Kesalahan, Kencana, Jakarta, 2006, hal. 98. 
Terhadap orang gila yang bersangkutan mendapatkan pembelaan dengan alasan penghapus pidana. Alasan terhadap sifat bagi penghapus pidana tersebut akan dapat terjadi karena kondisi dimana perbuatannya yang sebagaimana telah disebut diatas tidak dapat dipidanakan maupun atas perbuatannya tersebut yang tidak dapat dipidanakan. Atas alas an dalam hal penghapusan pidana tersebut, hal ini akan dapat dibedakan menjadi beberapa alasan, diiantaranya: Pada alasan pembenar (rehtsvardigingsground), pada alasan pemaaf (schuulduitsluitingsground), diantaranya merupakan bagian dari ketidak mampuan sifat bertanggungjawab sebagaimana telah termuat pada pasal ke 44 KUHP.

Disamping pada dasar dengan alasan sebuah penghapus kepidanaan yang sebagaimana telah termuat pada ketentuan perundang-undangan sebagaimana seperti diatas tersebut, Schafmeister, Keijeer dan Sutourius yang sebagaimana telah ada pada bukunya Choirul Huda mengatakan, telah masih ada sebuah alasan penghapus perbuatan kepidanaan sebagaimana berada diluar dari ketentuan peruundang-undangan yaitu pada kondisi dimana: a). Terhadap sebuah izin dan pada ketentuan keberlakuan norma-norma dalam jabatan yang sudah didapatnya tersebut (alasan dengan pembenar); b). Kesesatan (fakta maupun dari segi hukum), dan ketidakmampuan seseorang yang dapat dimaafklan (karena adanya sebuah alasan pemaaf). ${ }^{10}$

Terhadap tindakan yang sebgaimana dimkasudkan pada keadaan tidak dapat mempertanggungjawabkan sehingga dapat menimbulkan akibat dimana tidak dapat dijatuhi sebuah pertanggungjawaban kepidanaan. Artinya disnini, sewaktu telah ditemuka atau timbulnya tanda-tanda (penyebab) terhadap seseorang yang tidak mampu melaksanakan sikap yang bertanggungjawab serta karena dipandang bahwa tidak dapat mempertanggungjawabkan terhadap hal tersebut dalam ketentuan hukum kepidanaan, maka proses atas dasar pertanggungjawabannya tersebut akan berhenti sampai disini. Orang tersebut hanya dapat dikenakan atas apa yang telah diperbuatnya, tetapi tidak akan dapat dikenakan sebuah hukuman kepidanaan baginya tersebut. Dan juga, tidak pula perlu lagi diperiksa atau dilakukan proses lebih lanjut lagi apakah ada salah satu munculnya bentuk kesalahan maupun sebuah alasan penghapusan terhadap kesalahan yang ada pada dirinya tersebut. Sehingga, untuk dapat menyatakan bahwa seseorang tersebut akan mampu melakukan sikap yang bertanggung jawab yang akan menentukan dengan adanya faktor dari akal tersebut. Oleh karena itu, maka dalam hal tidak mampu melakukan atau menunjukan sikap yang dapat mempertanggungjawabkan, dimana keadaan akal pembuat perbuatan pidana tidak dapat bekerja dengan sebagaimana mestinya seperti orang normal pada umumnya. Ketidak normalnya fungsi akal orang tersebut, disebabkan oleh karena perubahan pada fungsi jiwa yang akan menyebabkan gangguan pada kesehatan jiwa.

Terhadap seorang pelaku yang melakukan perbuatan pidana akan tetapi dirinya tersebut tidak mampu untuk bertanggungjawab atas apa yang telah diperbuatnya tersebut oleh karena alasan-alasan tertentu yang hanya dapat dijelaskan berdasarkan dari sudut pandang dalam hal ini orang yang ahli di bidang kejiwaan dalam hal segi medis. Bagi hakim tersebut wajib menghadirkan seorang saksi ahli kejiwaan tersebut sehingga dapat menjelaskan kondisi perihal jkejiwaan yang dialami oleh tersangka terhadap kondisinya tersebut, sehingga mengakibatkan seorang pelaku perbuatan kepidanaannya akan dipandang ataupun dapat dinilai sebagai ketidak mampuan terhadap pertanggungjawaban yang dimilikinya. Menurut ketentuan Pasal ke 44 ayat ke 2 hakim dapat memasukkan ke rumah sakit jiwa selama satu tahun jika perbuatan itu tidak dapat dipertanggungjawabkan kepada terdakwa karna kondisi dimana kurang sempurna akal yang dimilikinya ataupun sakit berubah akalnya tersebut. Hal ini berarti bahwa seorang hakim dapat memutuskan hukuman secara lepas dari segala macam tuntutan hukum yang akan menjeratnya atas apa yang telah diperbuatnya atau sebagai tindakan untuk memerintahkan untuk memasukkan ke rumah sakit jiwa tersebut agar dirawat dengan prosedur yang sebagaimana mestinya. ${ }^{11}$

Di dalam ketentuan Pasal ke 44 ayat ke (1) KUHPidana yang pada intinya menyatakan bahwa: "Tidak dapat dipidananya seseorang yang dengan kondisi dimana barangsiapa yang melakukan suatu tindakan yang tidak dapat dibebankan atas pertanggungjawaban atas dirinya tersebut, yang diakibatkan oleh kurangnya atas kesempurnaan akal yang dimilikinya ataupun yang diakibatkan sakit berubah akal seseorang."

Ketentuan yang termuat di dalam sebuah ketentuan KUHP pada Pasal ke 44 ayat ke (1) tersebut menjelaskan terhadap kondisi dimana bahwa seseorang yang mengalami gangguan kejiwaan atau dikatakan lain dengan kondisi gila akan dibebaskan segala macam bentuk dari acam kepidanaan pada dirinya. Selanjutnya apa yang termuat pada ketentuan Undang-Undang Nomor ke 18 Tahun 2014 mengenai Kesehatan Jiwa pada diri seseorang, pada bagian Pasal ke 1 dinyatakan, bahwa yang dikatakan dengan kondisi dimana orang dengan kondisi gangguan kejiwaan merupakan orang yang telah mengalami kondisi gangguan dalam sebuah pikiran yang dimilikinya, perilaku pada dirinya, serta perasaan yang termanifestasi dalam bentuk sekumpulan pada gejala dan/atau perubahan atas perilaku yang bermakna, serta dapat mengakibatkan sebuah penderitaan maupun hambatan yang akan menggangu dirinya dalam menjalankan peran orang sebagai dirinya untuk menjadi manusia yang seutuhnya.

\author{
${ }^{10}$ Ibid., hal.114 \\ ${ }^{11}$ Andi Hamzah, Asas-Asas Bagian Hukum KePidanaan, Reneka Cipta, Jakarta, 2010, hal. 158.
}


Ruslan Abdul Gani, Pertanggungjawaban Pidana Bagi Pelaku Pembunuhan yang Mengalami Gangguan Jiwa Perspektif Hukum Pidana dan Islam

\section{Pertanggungjawaban Pidana Bagi Pelaku Yang Mengalami Kondisi Gangguan Jiwa Berdasarkan Hukum Pidana Islam}

Al-quran sangat melarang dan mengancam pelaku pembunuhan dengan ancaman neraka jahannam dan mereka kekal didalamnya serta Allah menyediakan azab yang besar baginya. Dilihat dari dasar Hukum terhadap larang untuk melakukan Perbuatan yang berkaitan dengan Kepidanaan atas perbuatan Pembunuhan dimana dalam ketentuan Islam, didasarkan kepada beberapa ketentuan, diantaranya pada:

1. Al-quran surah Al-Baqarah ayat 178 :

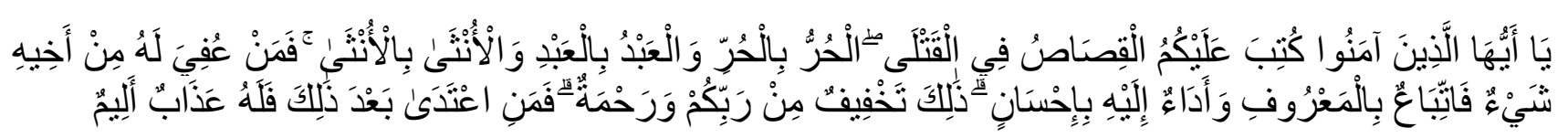

Artinya:'Hai orang-orang yang beriman, diwajibkan atas kamu qishaash berkenaan dengan orang-orang yang dibunuh; orang merdeka dengan orang merdeka, hamba dengan hamba, dan wanita dengan wanita. Maka barangsiapa yang mendapat suatu pemaafan dari saudaranya, hendaklah (yang memaafkan) mengikuti dengan cara yang baik, dan hendaklah (yang diberi maaf) membayar (diat) kepada yang memberi maaf dengan cara yang baik (pula). Yang demikian itu adalah suatu keringanan dari Tuhan kamu dan suatu rahmat. Barangsiapa yang melampaui batas sesudah itu, maka baginya siksa yang sangat pedih". ${ }^{2}$

2. Al-quran Surah An-Nisaa' ayat 93

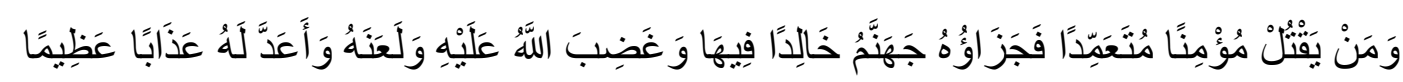

Artinya:'Dan barangsiapa yang membunuh seorang mukmin dengan sengaja maka balasannya ialah jahanam, kekal ia di dalamnya dan Allah murka kepadanya, dan mengutukinya serta menyediakan azab yang besar baginya." 13

3. Al-quran Surah Al-Maidah ayat 45

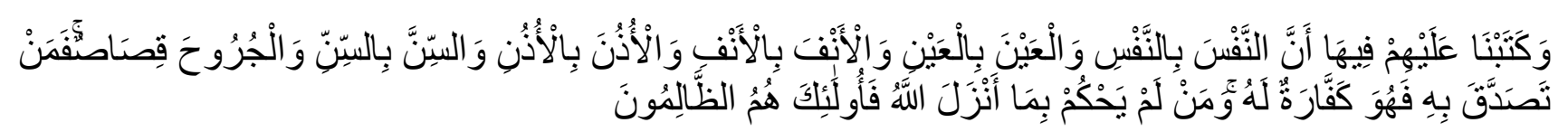

Artinya:"'Dan Kami telah tetapkan terhadap mereka di dalamnya (At Taurat) bahwasanya jiwa (dibalas) dengan jiwa, mata dengan mata, hidung dengan hidung, telinga dengan telinga, gigi dengan gigi, dan luka luka (pun) ada qishaashnya. Barangsiapa yang melepaskan (hak qishaash)nya, maka melepaskan hak itu (menjadi) penebus dosa baginya. Barangsiapa tidak memutuskan perkara menurut apa yang diturunkan Allah, maka mereka itu adalah orang-orang yang zalim." 14

4. Hadits riwayat Muslim

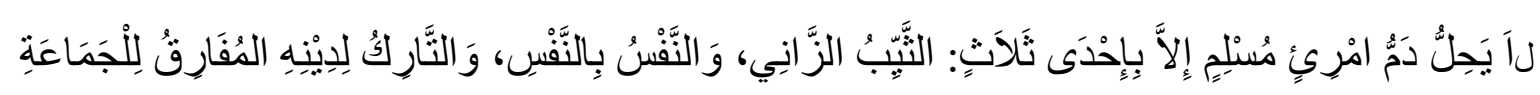

Artinya: 'Tidak halal darah seorang muslim, kecuali karena salah satu dari tiga hal: janda yang zina, jiwa yang membunuh jiwa. Dan orang yang meninggalkan agamanya yang memisahkan terhadap jama'ah. ${ }^{15}$

Berdasarkan ayat dan hadits di atas secara jelas dalam Hukum Islam dimana Islam melarang menghilangkan nyawa orang lain yang. membunuh tanpa alasan yang hak atau membunuh dengan sengaja para ulama untuk dengan sepakat mengatakan bahwa terhadap sebuah perbuatan yang mengakibatkan hilangnya nyawa orang lain tersebut akibat perbuatannya dan merupakan sebuah ketentuan hukum yang menyatakan reaksi atas perbuatan tersbut adalah hukumnya haram.

\footnotetext{
${ }^{12} \mathrm{Al}-$ Baqarah $(2): 178$

${ }^{13}$ An-Nisaa'(4) : 93

${ }^{14}$ Al-Maidah (5) : 45

${ }^{15}$ Rokhmadi, Hukum Kepidanaan Islam, Karya Abadi Jaya, Semarang, 2015, hal. 120.
} 
Dalam pandangan hukum Islam mengenai ketentuan hukum kepidanaan ini sering diartikan dengan sebuah kata dengan apa yang dikenal dengan sebutan jarimah dan jinayah. Hanya saja, terhadap ketentuan dalam Islam ini lebih di perjelas dengan ketentuan bahwa hukumannya ataupun atas pertanggungjawaban dari perbuatan dengan ketentuan kepidanaan ini akan berupa qishas dan hudud maupun ta'zir. Gila dalam hal pembunuhan secara umum terbagi dua, yaitu sebelum dan sesudah melakukan tindak pidana pembunuhan. Gila yang timbul sesudah seseorang telah melakukan tindakan jarimah, baik dari sebelum di proses pada pengadilan maupun setelah di proses oleh pengadilan.

Adapun tehadap sebuah pertaggungjawaban yang akan dikenakan kepada orang gila hal ini akan tentu dapat berkaitan dengan ketentuan kepidanaan ini akan dapat mengakibatkan kondisi yang berbeda-beda, dimana perbedaanperbedaan ini akan dipengaruhui oleh kondisi dua aspek, yaitu: dimana gilanya disertai jarimah atau terjadi sesudahnya oleh perbuatan itu. Adapun rinciannya adalah sebagai berikut:

\section{Gila mengiringi jarimah (perbuatan kepidanaan)}

Apabila atas dasar mengenai kondisi gila disertai sebuah tindakan yang menimbulkan sebuah ketentuan kepidanaan (dimana pada saat melakukan perbuatan tersebut dalam kondisi kejiawaan yang gila), maka pelakunya akan dilepaskan dari segala macam bentuk pertanggung jawaban pidana yang ada, oleh karena saat melakukan hal demikian diia tidak memiliki kemamuan pada dirinya idrak (berfikir). ${ }^{16}$ Para ulama telah menyatakan kesepakatan bahwa terhadap kondisi gila demikian sudah termasuk dari awaridhul ahliyah (hal yang akan menghalangi kondisi jatuhnya beban hukum bagi seseorang). Atas dasar ketentuan diatas didalam islam dilandasannya oleh sebuah hadits Rasulullah SAW yang berbunyi:

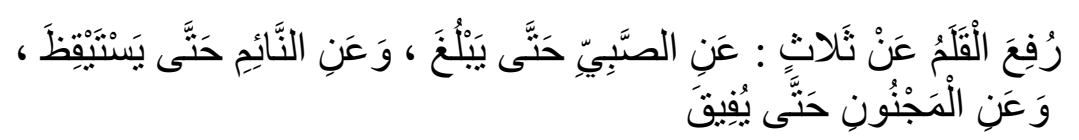

Artinya: "Pena diangkat dari tiga kelompok manusia: dari anak kecil hingga dia baligh, dari orang tidur hingga dia bangun, dari orang gila hingga dia sadar." (HR Ahmad). ${ }^{17}$

Berdasarkan atas penjelasan diatas dapat dipahami bahwa apabila seseorang yang telah mengidap penyakit dimana pada dirinya terdapat sifat gila atas dirinya yang akan melakukan sebuah tindakan jarimah al-hudud atau perbuatan pidana yang akan berkonsekuensi terkait dengan penegakan had, seperti perbuatan yang dilarang seperti: melakukan perbuata zina, menjadi seorang pemabuk, menajdi seorang pencuri dan lain sebagainya maka dia tidak akan terkena sebuah hukuman had atau dengan kata lain dinyatakan gugur atas segala macam bentuk perbuatan yang telah dilakukannya.

Adapun dalam perbuatan pidana yang akan berkaitan dengan konsekuensi qishash dan diyat. Maka terhadap orang gila itu tidaklah diqishash. Melainkan pada hukuman yang akan dikenakan pada dirinya akan diganti dengan uqubah Maliyah, yaitu dengan cara melakukan pembayaran dengan diyat. Hal tersebut dikarenakan oleh karena kejahatan yang akan berkaitan dengan hak-hak hamba itu tidak bisa digugurkan dengan sendirinya seperti halnya pada hak yang diberikan oleh Allah. Sedangkan terhadap perbuatan dimana pembunuhan yang telah dia lakukan itu akan disamakan dengan al-qathl al-khata'. Sebagaimana pendapat mayoritas sebagaian ulama selain Syafi'i menyebutkan "(perbuatan) yang disengaja oleh orang gila itu (dianggap) khata”

Apabila pada diri gilanya seseorang yang telah mengalami kondisi yang dinyatakan gila kemudian akan melakukan perbuatan pidana, maka terkait dengan pelakunya akan dibebaskan dari segala macam bentuk pertanggung jawaban pidana, oleh karena pada saat yang bersangkutan akan melakukan hal demikian tersebut maka dia tidak memiliki kemampuan untuk dapat membedakan apakah perbutan yang telah dia lakukan tersebut merupakan sebuah perbuatan yang dilarang ataupun tidak.

Terkait hal ini, bahwa pada dalam ketentuan tindak pidana yang telah berkonsekuensi qishash dan diyat. Maka, pada diri orang gila tersebut tidaklah di qishash. Melainkan pada hukumannya akan digantikan dengan uqubah Maliyah, yaitu dengan cara mengganti dengan sebuah cara lain dengan membayar diyat.

\section{Gila yang Datang Kemudian}

Bentuk gila seperti ini biasanya tampak pada saat diri seseorang telah melakukan jarimah atau perbuatan pidana, baik pada saat sebelum ataupun pada saat setelah sebuah proses hukum yang telah dilaluinya di pengadilan. Terhadap pendapat demikian diantara ulama ulama mempunyai pendapat yang berbeda: Menurut Syafi'iyah dan

${ }^{16}$ https://www.annursolo.com/pertanggunjawaban-orang-gila-dalam-kasus-pidana-menurut-islam/, $\quad$ akses $\quad 10 \quad$ Agustus November 2020

${ }^{17}$ Ibid 
Hanabilah, tidak menjadi hambatan bagi penegak hukum dalam rangka melakukan kondisi untuk menghalangi bahkan untuk menghilangkan sebuah proses hukuman, hal tersebut mengarkan kepada bahwa mereka akan tetap dijatuhkan hukuman berbentuk diqishas dan ataupun had meskipun pada diri pelakunya dalam kurang normal/kondisi gila dengan alasan apapun. Sanksi tersebut diberikan karena pelakunya telah memenuhi syarat taklif ketika melakukan tindakan pidana, Selanjutnya bila berpedoman kepada Madzhab Hanafiyah dan Malikiyah dimana Mazhab ini memposisikan bahwa pada seorang pelaku yang telah melakuakn sebuah perbuatan yang berkaitan dengan sebuah ketentuan kepidanaan yang setelah itu dirinya mengalami sebuah penyakit yang mengakibatkan dirinya menjadi gila ataupun tidak dapat dikenakan had dalam hal jarimah hudud hingga tersadar dari kondisi gilanya tersebut, hal ini dikarenakan pada penerapan had itu akan masuk juga dalam sebuah perkara taklif yang akan dikenakan pada diri orang gila tersebut, sedangkan pada kondisi mereka bukan lagi mukhatab ketika pada saat masa pengadilan maupun pada saat masa eksekusi oleh karena status gilanya yang telah mengakibatakan atas apa yang diperbuatnya tanpa kesadaran yang akan di kontrol olehnya. Untuk terpenuhi syarat legal dalam penegakan had menurut Hanafiyah jika terpenuhinya maka ketentuan taklifketika melakukan sebuah perbuatan pidana, akan saat pada masa pengadilan maupun pada saat eksekusi hukuman. ${ }^{18}$

Menurut hukum Islam, gila dalam hal pembunuhan secara umum terbagi dua, yaitu sebelum dan sesudah melakukan tindak pidana pembunuhan.Jadi, apabila pada kondisi gilanya dengan menyertai sebuah perbuatan pidana (pada saat melakukan sebuah kondisi dimana dalam kondisinya gila) maupun disebut gila sebelum perbuatan tersebut dilakukan, maka pelakunya akan dibebaskan dari sebagala macam bentuk pertanggungjawaban pidana. Namun jika dalam perbuatan pidana yang akan berkonsekuensi qishash dan diyat. Maka pada diri orang gila tidaklah di qishash. Melainkan pada sebuah hukuman yang akan diganti dengan uqubah Maliyah, yaitu dengan cara melakukan membayar diyat. Sedangkan gila sesudah melakukan tindak pidana atau datang kemudian baik sebelum atau setelah proses pengadilan, menurut pendapat Syafi'iyah dan Hanabilah tetap diqishas dan hal demikian akan dikenai had meskipun pada saat mereka telah mengalamai dimana dalam kondisi yang gila. Sedangkan, pada Madzhab Hanafiyah dan Malikiyah berpendapat tidak dikenai dengan apa yang dinamakan dengan had dalam jarimah hudud hingga dirinya tersadar.

Dilihat dari pertanggungjawaban pidana sebagaimana yang telah termuat dalam hukum ketentuan bagian hukum kepidanaan bagian Islam, Adapun, disini yang akan menjadi sebuah factor menajdikan seseorang pelaku yang akan dapat dimintai pertanggungjawaban kepidanaan terhadap perbuatan yang akan dilakukannya yaitu merupakan: Adanya pada perbuatan yang akan dilarang, maka perbuatan itu akan dikerjakan dengan cara pada diri perbuatannya itu sendiri dan pada diri pelaku telah mengetahui akibat dari perbuatan yang telah dilakukannya tersebut. Jadi, jika terdapat tiga hal tersebut maka akan terdapat pula pertanggungjawaban, dan hal ini kalau tidak terdapat maka tidak akan ada pula pertanggungjawaban pidana yang akan dibebankan. ${ }^{19}$

Ketiga unsur tersebut diatas, maka akan dapat diperoleh kesimpulan bahwa yang akan bisa dibebankan terhadap pertanggungjawaban pidana pada dirinya hanyalah pada manusia, yaitu manusia yang telah berakal pikiran sehat, dewasa dan serta memiliki yang berkemauan sendiri. Pada peristiwa pembunuhan yang terhadap orang yang mengalami gangguan jiwa tersebut, maka tidak akan dapat dijatuhi hukuman pada dirinya sebagaimana telah yang dijelaskan dalam H.R. Bukhari, Tirmidzi, Nasa'I, Ibnu Majah, dan Daru Qutni dari Aisyah dan Ali Ibnu Thalib.

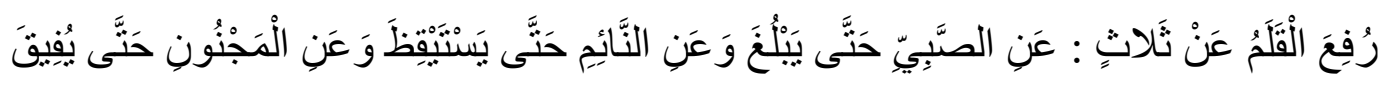

Artinya: Diangkat pembebanan hukum dari tiga (jenis orang); orang tidur sampai ia bangun, anak kecil sampai ia baligh, dan orang gila sampai ia sembuh..$^{20}$

Pada kondisi saat dimana kondisi gila tersebut tidak akan menjadikan suatu jarimah yang dibolehkan, melainkan hanya pada penghapusan sebuah hukuman yang ada pada dari pelakunya. Akan tetapi terhadap pembebasan pada orang gila dari hukuman tersebut, tidak berarti ia akan dibebaskan juga dari pertanggungjawaban perdata yang akan dikenakan pada dirinya, sebab harta benda serta jiwa orang lain dijamin pada keselamatannya oleh syara' serta alasan-alasan yang sah menjadikan kondisi dimana tidak akan dapat menghapuskan jaminan tersebut. Sebagaimana, pada diri orang gila masih tetap akan memiliki harta benda yang ada pada dirinya, ia juga dapat dapat dibebankan pertanggungjawabannya dari segi hukum perdata, yaitu pertanggungjawaban yang berkenaan berupa harta. ${ }^{21}$

\footnotetext{
${ }^{18}$ Ibid.,

${ }^{19}$ Ahmad Hanafi, Asas-Asas Bagian Hukum Kepidanaan, Bulan Bintang, Yogyakarta, 1968, hal. 154

${ }^{20}$ Muhammad Ibnu Isma'il, Sanksi Bagi Pelaku Tindakan Pembunuhan Berdasarkan Hukum Islam Islam, Sinar Grafika, Jakarta, 2010, hal. 45.

${ }^{21}$ Abdul Qadir Audah, Ensiklopedia Pada Bagian Hukum Kepidanaan Islam, Aneka Ilmu Semarang, 2010.hal. 71.
} 


\section{SIMPULAN}

Pertanggungjawaban atas pidana yang diperbuat oleh pelaku yang sedang mengalami sakit berupa Gangguan Kejiwaan Menurut Hukum Pidana Indonesia, tidak dapat dimintai pertanggungjawaban karena hal ini berkaitan dengan tujuan dari penghukuman itu sendiri dimana tujuannya adalah untuk memperbaiki kesalahan yang dilakukan oleh terpidana setelah menjalani hukuman. Untuk itu agar pembinaan yang diberikan selama masa menjalani hukuman tersebut dapat dijalaninya tentunya dalam hal ini kondisi kejiwaan terpidana dalam keondisi sehat tidak sedang mengalami sakit jiwanya. Ketententuan tersebut sebagaimana diatur dalamPasal 44 KUHP ayat (1) KUHP.

Pertanggungjawaban atas pidana yang diperbuat oleh pelaku yang sedang mengalami sakit berupa Gangguan Kejiwaan Menurut Hukum Pidana Bagian Islam, sama dengan hokum Pidana yang berlaku di Indoneisa, yakni dibebaskan dari segala hukuman pidana, akan tetapi yang bersangkutan tetap dikenakan pertanggungjawaban perdata yang berkaitan dengan harta apabila yang bersangkutan memiliki harta kekayaan.

\section{DAFTAR PUSTAKA}

\section{Buku}

Ali, Zainuddin, Pengantar Ilmu Hukum Kepidanaan Islam Di Indonesia, Sinar Grafika, Jakarta, 2006.

Audah, Abdul Qadir, Ensiklopedia Pada Bagian Hukum Kepidanaan Islam, Aneka Ilmu Semarang, 2010.

Hamzah, Andi, Asas-Asas Bagian Hukum KePidanaan, Reneka Cipta, Jakarta, 2010.

Hanafi, Ahmad, Asas-Asas Bagian Hukum Kepidanaan, Bulan Bintang, Yogyakarta, 1968.

Isma'il, Muhammad Ibnu, Sanksi Bagi Pelaku Tindakan Pembunuhan Berdasarkan Hukum Islam Islam, Sinar Grafika, Jakarta, 2010.

Maryati, Kun dan Jujun Suryawati, Sosiologi Jilid3 , ESIS, 2001.

Muslich, Ahmad Wardi, Hukum Kepidanaan Berdasarkan Al-Qur'an, Diadit Media, Jakarta, 2007.

Rokhmadi, Hukum Kepidanaan Islam, Karya Abadi Jaya, Semarang, 2015.

Santoso, Topo, Membumikan Bagian Ketentuan Hukum Kepidanaan Islam, Gema Insani Press, Jakarta, 2003.

\section{Internet}

https://www.annursolo.com/pertanggunjawaban-orang-gila-dalam-kasus-pidana-menurut-islam/, akses 10 Agustus November 2020 